\title{
RUNAWAY WIVES: HUSBAND DESERTION IN MEDIEVAL ENGLAND
}

\section{By Sara Butler}

\section{Loyola University New Orleans}

Scholars of the medieval family would generally agree that the lot of the medieval wife was not an easy one. Medieval husbands held the upper hand in the power relationship, both legally and socially. Although Lawrence Stone's view of married life in the Middle Ages as "brutal and often hostile, with little communication, [and] much wife-beating" has since been called into question, more recent historians have still painted a somewhat unflattering picture. ${ }^{1} \mathrm{Ju}$ dith Bennett writes that "[m]edieval people thought of conjugality as a hierarchy headed by a husband who not only controlled his wife's financial assets and public behavior, but also freely enforced his will through physical violence." 2 Indeed, she argues that wife-beating was "a normal part of marriage." "Even Barbara Hanawalt, who has optimistically described peasant marriage in medieval England as a partnership, still concedes that occasional violence was acceptable and expected in marriage. ${ }^{4}$ What is more, the rules of coverture, which adhered to the biblical principal of husband and wife as one flesh represented at law by the husband, left a wife economically vulnerable. Because all real and movable property legally belonged to the husband as head of the household, a wife who fell out of favor with her husband might well find herself expelled from the family home, without any resources to fall back on. ${ }^{5}$ From a modern perspective, marital practices hardly provided any sense of reassurance. At a time when families, more often than individuals, took the lead in spousal selection, and inheritance and status were the chief criteria, strong bonds of affection were not guaranteed. Up against all these factors, some medieval wives might have found their fates difficult to accept. That is not to say that all medieval marriages were prisons instead of playgrounds, but the potential for prolonged marital discontent was notably higher then than it is now. ${ }^{6}$

Despite this dreary image of medieval marriage, wives generally accepted their position-and not just passively. Some women actually fought to hold on to their wretched marriages, even when it was clear that their husbands were desperate for an annulment. In examining the records of marriage litigation at the consistory court of York in the 14th and 15th century, Charles Donahue, Jr. makes a number of striking observations. He notes that not only were women more persistent in suing their cases, but they were far more likely to sue to enforce a marriage than were men (even when the financial benefits "were not obvious") and far less likely to dissolve a marriage than were men. ${ }^{7}$ Andrew Finch, in his comparison of the dioceses of Hereford and Cerisy, makes a similar observation. ${ }^{8}$ Findings of this nature would seem to suggest that women would do almost anything for the security of marriage, even if it meant staying in an unhealthy marriage, or with a man who would really rather be married to someone else, as was often the case in multi-party litigation where precontract (bigamy) was the issue at contest. At any rate, Donahue's portrayal of the church courts as 
overwhelmingly pro-plaintiff reveals that many women got what they wanted. ${ }^{9}$ Because the medieval church was even more determined to uphold the sacrament of marriage, female plaintiffs found a powerful ally in the courts and were often successful in their suits.

This picture of "desperate housewives" needs to be revised—or at the very least, complemented with the image of women who were equally resolute to escape marital misery, even if it meant defying society, the church and the law. Over the past two decades, a number of historians have presented evidence to challenge this point of view. R.H. Helmholz has proposed that "self-divorce" among the medieval English may have been more common than we think. ${ }^{10}$ Sue Sheridan Walker and, more recently, Henry Ansgar Kelly have put forward similar suggestions in their studies of cases of ravishment, or "consensual abduction." 11 The goal of this paper is to provide a more comprehensive perspective of husband desertion, including the risks involved in deserting one's husband, the wife's motivations, and the logistics of desertion (where did she go? Who assisted her?). Examining 121 cases of husband desertion from the records of these three judicial systems from the fourteenth to early sixteenth centuries, this paper will highlight cases of wives who refused to remain in unsatisfactory marriages. This paper hopes to offer a better understanding of the risks involved in such an undertaking, as well as contemporary attitudes toward runaway wives as evidenced through the legal record.

\section{A Brief Note about Numbers}

Although historians of the law usually divide along jurisdictional lines, the courts of medieval England did not have clearly defined boundaries; thus, as Daniel Klerman has demonstrated, medieval litigants, determined to find a resolution to their problems, cared less for the nature of the court than for the possibility of a favorable judgment. ${ }^{12}$ The ecclesiastical courts were the most obvious forum for dispute in a moral issue such as spousal desertion; nevertheless, cases relating to this matter also appear in secular courts, both royal and manorial. An analysis of cases drawn from all three venues provides the clearest understanding of a husband's options in an effort to either retrieve his wife or punish her and those who assisted her. In the church courts, evidence of desertion emerged in cases of abandonment, spousal non-cohabitation, and restitution of conjugal rights. Thus, this study examined all marital causes for the northern and southern ecclesiastical provinces (York and Canterbury), as well as records of the dioceses of York, Canterbury and London. In addition, archbishops' and bishops' registers, which exist in abundance in print form, have also been included. In most other courts (common and manorial), desertion was alleged in a more covert manner as a suit of ravishment, with the husband suing for the loss of the goods taken with his wife. For manorial courts, the analysis was much more select, including cases only for Yorkshire, especially Wakefield, Sheffield, Thorner, Pontefract, Bradford, and Tickhill Honour. For royal records, printed records of common law cases drawn from quasi-criminal cases (sessions of the peace) and civil suits (Court of Common Pleas) have been combined with manuscript records of royal indictment from both York and Essex. In Chancery, although some suits of ravishment also appear, accusations of deser- 
tion more usually were brought up in cases of harassment where the victim was the jilted husband. This paper examined all marriage-related records from the late medieval court of Chancery. From these records, 121 cases of specifically husband-desertion have been drawn for discussion.

This grouping of 121 cases represents only a small fraction of actual cases of husband desertion from medieval England in this period. This paper does not aspire to a thorough examination of all possible records; rather, the hope is to provide a sampling from the records in order to demonstrate the possible outcomes and risks in cases of husband desertion. Nonetheless, even a comprehensive analysis of all records could not possibly uncover all actual instances of husband abandonment. Desertion is inevitably under-represented in the case numbers for several reasons. Most obviously, many spurned husbands were probably unwilling to admit publicly that their wives had left them. Abandonment by a wife was explicit evidence of a husband's inability to govern his household properly; thus, many husbands may well have been too embarrassed to inform the courts. More important still, only those couples whose separations had become notorious seem to have been brought to the attention of the parish priest. Separated wives (or husbands, for that matter) who went on to engage in adulterous relationships or even other marriages, were the chief offenders. It is not hard to imagine that husbands and wives who led chaste lives or moved to new communities may have easily escaped notice. Finally, it is important to recog. nize that the records themselves can be somewhat misleading. In this paper, the focus is on those cases where the records make it clear the wife was the deserter. But often, when dealing with separated couples, the records give no sense of who left whom. It is usually when one party was contumacious that we have a chance to discover who took the initiative. Thus, with the many, many cases of spousal non-cohabitation presented in the courts of medieval England, it is often impossible to discover whether the wife deserted her husband, or if it was the other way around. ${ }^{13}$

All of this leads us to the conclusion that we cannot focus on the numbers of wives who left; rather we must focus instead on what these cases can tell us about runaway wives.

\section{The Risk Factor}

Today, many women stay married to incompatible or even abusive men because they fear the alternative: economic vulnerability, custody disputes, even social or familial ostracism, despite the fact that we live in a world where divorce is available at law and a very common feature of our society. For women in medieval England, the stakes were much higher. Although alimony did exist in this period, and there are surviving examples of maintenance agreements, enforcing those agreements was next to impossible, and most women could not have relied on alimony for full support. ${ }^{14}$ The statute of Westminster II (1285) complicated a deserted wife's financial stability. The statute declared that an adulteress was ineligible to claim dower rights after the death of her husband unless he had forgiven her, without any coercion from the church, and the two were reconciled at the time of his death. ${ }^{15}$ Not all wives who deserted their husbands became adulteresses, but many did. Thus, a wife who deserted her husband and moved 
on with her life might lose any hope of financial security even after her husband's death. More to the point, it was unlikely that a woman on her own would have been able to support herself financially. As Ruth Mazo Karras has observed, one of the reasons why the term "singlewoman" was virtually interchangeable with "prostitute" in this period is because singlewomen often had to resort to sex for money at some point just to stay alive. 16

A wife's position in the social hierarchy was another weighty consideration. Just being married made a wife someone important, and provided many wives with enough satisfaction to make a bad marriage tolerable. As Judith Bennett and Amy Froide have argued, "marital status shaped women's lives ... [w]ives were assumed to be better governed than other women ... [and] wives could exercise some informal political power through their husbands."17 What is more, in a world where most women were reared with the sole purpose of getting married, a wife could be secure in the knowledge that she had fulfilled her Christian duty, and thus had earned the respect of her community for doing so.

Desertion also had significant spiritual risks. The church courts were determined to keep marriages together. By the early thirteenth century, the medieval church undertook the mission of making marriage a sacrament, thus church courts firmly upheld the biblical directive of "what God has joined together, let no man put asunder" (Matt. 19.6). A woman who left her husband, without first obtaining an annulment or a court-approved separation (neither of which was very easy to acquire) put herself in spiritual jeopardy. ${ }^{18}$

Despite these factors, women did desert their husbands, and sometimes refused to go back. However, one of the greatest perils faced by runaway wives was in confronting the law. For those cases where the husband wanted his wife back (or the goods she had taken with her, as was more commonly the case), and sought the assistance of a court to do so, the medieval courts had serious weapons at their disposal.

Church courts sometimes used threats of excommunication to coerce wives into returning to their marriages. For some wives, the threat itself proved to be a potent weapon. ${ }^{19}$ Other wives did not appear in court to submit to this kind of intimidation. Women like Emma Herevay persisted in spite of the warning. In 1336, when Emma was brought before the court of the dean and chapter of Lincoln and told to adhere to her husband under pain of excommunication, she was adamant in her refusal, saying that she would not return. ${ }^{20}$ For wives like Emma Herevay, the intimidation tactics moved beyond intimidation to having sentences of excommunication carried out against them. Varying degrees of excommunication were imposed. In June of 1463 when Katherine Kyrton failed to appear in court on charges of refusing to cohabit with her husband John Kyrton, the dean of Wisbech suspended her. ${ }^{21}$ Suspension is a minor form of excommunication, which requires exclusion only from the Eucharist and the sacraments. Thus, it is an expulsion from the church, but still permits inclusion in the wider community. Most cases were not treated with such lenience. Christine Verner, cited in 1388 by the bishop of Salisbury for not consorting with her husband, was just one of many women who experienced major excommunication for her contumacy. ${ }^{22}$ Major excommunication required full social exclusion-Christians were bound to avoid any contact or interaction with an excommunicant. Excommunicants also existed outside secular law: they could 
not sue in civil litigation or accuse in criminal trials, and thus suffered a serious legal disability.

Excommunication, of course, was meant to be a temporary state, until the sinner came to his or her senses and began the penitential process. However, in those cases where the excommunicant remained obstinate, after 40 days the church was permitted to employ the secular arm of the law to arrest and imprison the excommunicant until he/she declared a willingness to submit to ecclesiastic jurisdiction. Cases of desertion show that the courts did not shy away from calling in the local bailiff to collect stubbornly excommunicant runaway wives. In March of 1419, the archbishop of Canterbury requested assistance from the secular arm in the capture of Lady Margery of Longford in Staffordshire, a woman of very comfortable means, excommunicated for her continued refusal to obey orders for restitution of conjugal rights, despite the fact that she allegedly had simultaneous suits in both the church court and Chancery to work out a judicial separation. ${ }^{23}$ The bishop of Durham made a similar request in the year 1417 to the lord of the liberty of Tynedale for assistance in the arrest of Joan Buntyng, excommunicated for more than forty days for neglecting to adhere or cohabit with her husband Alexander. ${ }^{24}$ It may be significant that in the first case, at least, it is clear that the deserting wife was a land-owning woman of some importance, and thus a more drastic form of coercion may have been considered necessary. It is not clear whether the secular arm of the law was only brought in when money was at stake. Nevertheless, the church's willingness to impose the full weight of the law on these women demonstrates that they perceived desertion to be a grave matter, and were determined to make an example of these women. It also underscores the danger of deserting one's husband: excommunication and imprisonment were serious penalties.

The secular law courts as well provided useful tools to coerce husbanddeserters into a change of heart. The manorial courts, on the one hand, did not frequently address husband desertion, although marital disputes in one form or another regularly appeared in these courts. ${ }^{25} \mathrm{~A}$ manorial roll from the court of Wakefield in 1331 records the appearance of three men, Robert de la Bothe, Adam Kenward, and Adam de Holne, who state that they have in their custody 60 s. worth of goods belonging to Thomas son of Alice and his wife Agnes. They add that if Agnes is willing to be "duly reconciled" to her husband, the couple can have those goods back. ${ }^{26}$ Detainment of goods as a surety for good behavior was a common tool imposed by the manorial courts to maintain order in the community. Although this is the only case of this nature uncovered by this study in the manorial courts, it does suggest that this process might have been useful in reconciling couples.

The common law courts, on the other hand, were more experienced in addressing husband desertion, and the families and friends of runaway wives sometimes found themselves subject to prosecution in these courts. Trespass cases from the court of Common Pleas provide insight into cases of consensual abduction - wives who deserted their husbands with the help of a friend or family member. If the woman left with goods from her household, under the law, those who assisted her might be subject to charges of ravishment. ${ }^{27}$ The goal of a suit of ravishment was the return of the goods taken with the wife, not the wife herself. Because marriage is a sacrament, royal justices considered a husband and wife's 
relationship to be in the hands of the bishop. As J.B. Post has argued, in cases of ravishment, the issue at stake was consent. Whether the wife consented (either before or after) to her abduction was not a vital concern. If the act was contrary to her husband's consent, however, the abduction might be sued as a case of ravishment. ${ }^{28}$ For example, when Isabel wife of Robert Bull "returned of her own free will" to her father's home after a short period of marriage in which her husband was caught "misbehaving with other women," her father soon found himself up on charges of ravishment as a trespass in the king's courts. ${ }^{29}$ Beatrice daughter of Sabina Herring similarly endangered her family. Although she had been forced into marriage "against her will" by Henry le Welye while she was under age, Henry still felt confident enough in his position to plead a suit of ravishment against Beatrice's mother and uncle for aiding in her escape. ${ }^{30}$ The case of Isabel wife of Bartholomew Ware shows that the courts sometimes interpreted "ravishment" as merely offering a runaway wife a place to stay. When Isabel discovered that she was more closely related to her recently espoused mate than she had believed, "in order to avoid the peril of sin in salvation of her soul and her Christianity," she sued for an annulment, which the church eventually granted. While the process was pending, the archdeacon of the monastery of Westminster decreed that Isabel should live outside the company of her husband until the case was fully resolved, and so she divided her time between the homes of her adult son and daughter from a previous marriage. Both her son and her daughter's husband soon found themselves accused of ravishment. ${ }^{31}$

Cases of ravishment also appeared in the manorial courts. For the plaintiff (that is, the abandoned husband), this was a far superior venue. As Maureen Mulholland has observed, the common law courts did "not provide quick, simple and accessible justice in minor local disputes." ${ }^{32}$ Manorial courts did. There were no costly writs and the litigants were not required to travel or pay the costs for witnesses to travel. The manorial courts also did not require the involvement of significant sums of money, whereas those suits brought to the king's court usually did. ${ }^{33}$ Thus, John Werkman of Earls Colne manor in Essex was capable of winning his suit against John Crudde for entering his enclosure during Pentecost of 1402 and abducting only his wife-he did not also have to assert the theft of goods or chattels. ${ }^{34} \mathrm{~A}$ jury of one's peers, equipped with a more intimate knowledge of the various personalities involved in the case, might have been more inclined to sympathy than a group of strangers. This may well explain why John Werkman won damages of $6 s .8 d$.

In those actions of ravishment appearing in common law courts as a trespass, a conviction would result in the accused paying an amercement, usually the equivalent of the goods allegedly stolen from the husband in addition to damages. At times, the amounts awarded were substantial. For example, Robert de Heydon, the former apprentice of Stephen de Upton, accused of ravishing his wife, was ordered to pay sixty pounds for the goods and chattels he "maliciously carried away." After damages, his total bill came to $£ 12613 \mathrm{~s} .4 d^{35}$ If he was not capable of paying this bill, he risked being imprisoned coercively until he found a way to pay it. While this process was certainly embarrassing, financially taxing, and frustrating to those women and their families who, no doubt, saw those "stolen goods" as rightfully belonging to the wife, trespasses of rav- 
ishment generally inflicted no additional damages. A conviction in either court also resulted in no physical penalties. Much more dangerous were those cases where husbands instead chose to plead their wives "abduction," as a felony of rape with the much greater penalty of death. Felonious suits of ravishment in the king's courts fell into the same category as cases of rape, and in fact were often indistinguishable from them. As Emma Hawkes notes, "medieval legal records generally blurred the two crimes together." ${ }^{36}$ Because the term "rape" was so illdefined in the medieval period, jurors had to be very careful in the wording of indictments to distinguish between cases of rape in which sexual assault seems to have been the primary offence and cases of ravishment, or abduction, where the wife was often a willing participant. ${ }^{37}$ The statute of Westminster II (1285) attempted to standardize the vocabulary of ravishment by combining the term "rape" with a qualifying term like "abduct"(rapuit et abduxit). For a sexual assault, a jury would employ the verb rape (rapuit) on its own. Although many modern historians have been "repelled by the ambiguities and vagueness of the statutes and by the inconsistencies in the prosecution of these laws," medieval juries were diligent enough in the use of conjunctive vocabulary that many cases of ravishment can be found among the felony suits of the records of the king's courts. ${ }^{38}$ For example, when Roger de Harleston, archdeacon of Cambridge and Henry de Bongheye came to Walden Abbey in June of 1349, the records note they feloniously raped and abducted (felonice rapuerunt et abduxerunt) Katherine wife of Hugh Veysee, and feloniously carried away goods of the said Hugh to the value of forty pounds. ${ }^{39}$ Some juries went to extremes in their wish to clarify the nature of the offence. For example, when Thomas Walsshman, a tailor, entered the home of Stephen Irish, he is said to have taken and abducted and raped (cepit et abduxit et rapuit) both Stephen's wife, Alice, and his goods to a value of forty pounds. To underscore the ravishment even further, Thomas is said to have taken both Stephen's wife and the goods far from Coventry (ac de villa Couentre longe duxit). ${ }^{40}$ At other times, the term "rape" is omitted altogether, most likely because juries knew how confusing it could be. When William Beverel, chaplain, entered the close of Matthew Gardrobier in the ville of Plessis and abducted the wife of the said Matthew, as well as goods worth ten shillings, he is said to have taken and abducted her against the peace (contra pacem cepit et abduxit). ${ }^{41}$ When Matthew Pye de Crauncewyk came to the home of John Fissher at Watton (Yorks.), he is reported merely as having "led away" (minavit) John's wife. ${ }^{42}$

The use of these qualifying terms ensured that trial juries knew exactly what had transpired, and thus it should come as no surprise that they were unwilling to convict any of the "rapists" in situations where the crime was clearly a case of ravishment. Quite simply, death did not seem a fitting punishment for a man whose guilt lay in helping or seducing a consenting woman. Even without the death penalty looming over a man's head, the impact on the accused would have been substantial. Damage to one's reputation from the indictment was sufficiently injurious. Add to that the arrest, imprisonment awaiting trial for probably a year or more, which meant living in unpleasant living conditions and not being there to help one's family support themselves, and paying the travel costs of any necessary witnesses. With such high stakes, it is remarkable 
that anyone was willing to assist those unhappy wives and thereby risk being labeled a "rapist." To add insult to injury, after the kafuffle of the royal courts, the well-meaning rescuer of an unhappy wife might also find himself in trouble with the church. For example, the register of the Palatinate of Durham from the year 1339 includes a case of wife robbery (causa spoliationis uxoris). In response to Richard de Hyd's complaint that William then of Gourtone had robbed him of his wife of thirteen years, the bishop issued a mandate to the official of Alverton demanding justice be done to Richard. ${ }^{43}$ And this was not the only case of spousal abduction to appear in the ecclesiastical courts. ${ }^{44}$ England's multiple and often complementary judicial systems were usually an asset to Englishmen and women hoping to find justice; for runaway wives, however, multiple courts merely provided multiple means of penalizing those who assisted her in her desertion.

Although the secular courts insisted that suits of ravishment be sued against the "abductor" (because of the legal difficulties of a husband suing his wife under the rules of coverture), the wife might also find herself in trouble with the law, arrested for stealing from her husband. A tourn at the manor of Wakefield (Yorks.) in 1286 notes: "John son of Sybbe and Cicely wife of Adam the Miller, carried off the said Adam's goods in the night. They are to be arrested." 45

For most wives, probably the greatest risk was a forced return to an unhappy marriage. ${ }^{46}$ For those wives who did agree to return to their husbands, often they did so with a threat hanging over their heads of future penance should they fail to become model wives. For example, in June of 1412, Katherine wife of John atte Mulle, who not only left her husband, but also wasted his goods, was sworn to stay and look after him on pain of $100 \mathrm{~s}$. and six beatings through the marketplace. ${ }^{47}$ Similarly, in July of 1347 , Isabel wife of Robert atte Kyrk, guilty of both desertion and adultery with the local chaplain, was required to cohabit with her husband Robert and "to treat him peacefully and quietly and to humbly obey him and not provoke his anger" on pain of six beatings around the marketplace of Grantham and six around the church of Skelinton, dressed only in a nightshirt. ${ }^{48}$ These were typical monitions, imposed by the church for a variety of other penances, from fornication to adultery to a cleric's breaking his vow of celibacy. In cases of desertion, however, they take on special meaning. Here, these warnings are not just about sin-they are also about reinstating the marital hierarchy for a wife who did not know her place. Wives were frequently instructed to promise obedience to their husbands and, at times, might be summoned before the court to respond to allegations of disobedience ${ }^{49}$ For example, in a mandate to the dean of Worcester in 1275 regarding the complaint of Richard Caylott that his wife Christiana atte Wode was not obedient to her husband, the bishop of Worcester wrote: "there is a natural order of mankind that women should serve their husbands ... [thus] the dean is ordered to warn the said Christiana, and induce her to be obedient to her husband in all lawful and honest matters, and treat him with wifely affection." 50 With the very real threat of further penance hanging over her head if she failed in her wifely duty, a reunited wife must have been all too conscious of the simple fact that her recently estranged husband was the final judge of whether or not she had fulfilled her promises. 
The church courts' judgments were usually effective immediately, even though some of these separations were lengthy. As an example, when Joan the mistress of John Comyn appeared before the court to hear accusations of adultery and husband abandonment, we are told that it had been six years since her desertion. ${ }^{51}$ When Joanna Apulbe was cited in the diocese of Lincoln for failing to cohabit with her husband, the record notes that they had not lived together for four years. ${ }^{52}$ After such a protracted interlude of estrangement, it might have been difficult for couples to get used to the idea of being reunited. Occasionally, the church showed some compassion to the wife by giving her time to prepare for the transition. For example, Emma wife of Nicholas Swayn was given 8 days with which to return to her marriage; Isabel Poterne was given three weeks. ${ }^{53}$ The more common sentiment, however, seemed to be that as expressed to Margaret wife of John Cutte of Drayton, told to resume her marriage "without delay" (sine dilacione). ${ }^{54}$

Making the decision to leave one's husband was not easy in the medieval context. Wives had much to fear: from excommunication to imprisonment to forced reunion. Because those who assisted a deserter risked imprisonment, penance, weighty fines, and death (although the latter seems to have been in theory rather than in practice), many families and friends must have been dogged in their determination to keep married couples together, if only to save their own purses and reputations. A wife eager to abandon her husband had good reason to believe she might have difficulty finding supporters among her family and friends. And yet, women did choose to lead separate lives and some of their families and friends supported them. In light of all these obstacles, it would seem that those wives who deserted their husbands must have had good reason.

\section{Why did they leave?}

This grouping of cases cannot tell us all the reasons why marriages dissipated in medieval England. R.H. Helmholz's work on this subject highlights the centrality of precontracts (bigamous relationships), fears of consanguinity, and general discontent. ${ }^{55}$ In the sampling of cases under investigation here, the vast majority reveal no reason why the wife abandoned her husband. To offer an example of the paltry detail included in some of these records: the register of the bishop of Salisbury for the years 1388-1395 notes the case of Katherine atte Borwe, "who will not consort with Philip, her husband, nor receive him in her house, nor share any of her goods with him." We are told that Thomas Cuttyng abets her; but otherwise, the reader is left to imagine exactly what transpired, and whether Cuttyng was a lover, a brother, or a neighbor. ${ }^{56}$ Another case from the diocese of Salisbury, 1409: "Isabel Cras of Lechelade cited for not living with [her] husband; did not come; suspended." ${ }^{57}$ An even less informative notation: "Agnes Bevre does not adhere or consort with John Brewer her husband." ${ }^{8} \mathrm{Re}$ grettably, for cases of this nature, not a lot can be discovered about a woman's motivation.

Some records hint to reasons why women left their husbands. One wife was thought to have left her husband because of physical infirmity. The register of the bishop of Salisbury for the years 1388-95 notes the case of Agnes Wormes 
who left her blind husband, Ralph Irwyn, and reportedly refused him conjugal rights. ${ }^{59} \mathrm{~A}$ good number of women were in the process of formalizing their separations when their husbands initiated suits against them in other courts. When the secular arm of the law was raised to capture Lady Margery of Longford, she had already initiated an application for a judicial separation and brought a bill before Chancery, as mentioned above ${ }^{60}$ She was not the only one. A case brought before the mayor's court of the City of London in 1305 notes that, because of a delay in addressing the complaint brought by William de Lyndesseye for goods worth $£ 20$ that his wife had "eloigned into the houses of William de Wynchelsee," a judicial separation had been celebrated between them in the face of the Church (celebratum in facie ecclesie) and the goods had already been delivered to Alice by the undersheriff. ${ }^{61}$ Many other women, usually those fending off husbands looking for lost goods, claimed that annulments had already been granted to them for their marriages for a variety of reasons, from precontract to consanguinity. ${ }^{62}$ In the case of Agnes Mortimer, her marriage with Simon Barber had already been annulled before the archdeacon of London when Simon decided that he wanted her back. By the time his case of ravishment came before the court in 1369, she was married to her "rapist."

Where a marriage terminated in annulment, often the records give a reason; in cases of judicial separation, however, the cause is usually omitted, as was the case with both Margery of Longford and Alice the wife of William de Lyndesseye discussed above. The most likely reason to grant a judicial separation, however, was cruelty (saevitia), the ecclesiastical phrase used to denote spousal abuse. ${ }^{64}$ Although cases of cruelty rarely appeared in the courts, other wives also alluded to the possibility of abuse. For example, only after seeing her excommunication in writing would Margaret wife of John Cutte of Drayton allow herself to be coerced into reuniting with her husband, but she did so on condition that "her husband treat her in future well, decently, and favourably," a guarantee often sought by victims of abuse when forced to return to their spouses. ${ }^{65}$ At times, wives were quick to resort to cruelty as a defense for their desertion. The wife of Henry Cook of Trottiscliffe told the court of Rochester in 1347 that her husband had been both unfaithful and cruel. ${ }^{66}$ Lady Christiana Meynell, accused by her husband of trying to poison him in the year 1292, claimed that she was forced to leave her husband because of his cruelty ${ }^{67}$ In a case of abduction from the court of King's Bench in 1366, we hear the story of Joan wife of Philip de Moulsham, who was coerced into marriage with him after she was engaged to John Cookshe later escaped Philip's custody and married John. ${ }^{68}$

Sexual dissatisfaction may have been a more common motivation for desertion than one would think for this period. The medieval church was cautious in its approach to cases of impotence. If a marriage could not be consummated because of the impotence or frigidity of one of the spouses, and the canonically prescribed trial period of three years had passed, then the church would grant an annulment. ${ }^{69}$ This rigid policy created some obvious problems. In a world where femininity was equated with motherhood, many women must have experienced disappointment and a sense of inadequacy waiting three years for their annulment. At the same time, what about those couples where problems with impotence developed after the marriage had been consummated? Augustine ar- 
gued that marriage was a necessary remedy against sin; and the church, in its regular prosecution of fornicators and adulterers held Christians to that standpoint. For the wives of impotent men, however, it was not much of a remedy.

The discontent of women to remain with impotent men is echoed in at least two of the cases of runaway wives. An ex officio case from the act book of the diocese of Canterbury, which spans the years 1395-1410, recounts the story of Helen daughter of Juliana Hewet. When Juliana Hewet was summoned before the court accused of pimping her daughter, she and her daughter both appeared in court to deny wholly the allegations. Instead, Juliana argued that she had abducted Helen from her marriage. When asked why she refused to adhere to her husband, Helen replied that her husband was impotent. As an added insult, she was now in the custody of an "honest man," with whom Helen had since become pregnant and given birth. ${ }^{70}$ The record makes no mention of a suit for annulment on the grounds of impotence, presumably a critical detail that would have been included if had been the case. The birth of a child so soon after her "abduction," however, makes two points clear. First, Helen was not to blame for the barren marriage. Second, being a mother was an important role she was eager to play.

A wife's wish to escape an impotent marriage was complicated by issues of masculine reputation. After all, what man wanted his wife suing for an annulment on the grounds of impotence? When Henry, vicar of Swalcliffe appeared before the court of King's Bench in 1388 to respond to allegations of abducting Alice wife of John Wyatt and goods belonging to her husband, the story he presented demonstrates that some husbands might have reacted violently to the very suggestion of desertion on these grounds. Apparently, when Alice decided to sue for an annulment before the archdeacon of Oxford because of her husband's impotence, she was counseled to leave her husband during the course of the proceedings, "because the said John Wyatt threatened the same Alice in life and limb because of her aforesaid suit not only before the said official there but also elsewhere before various law-worthy persons." Fearing for her life, Alice sought permission from the archdeacon to live in the custody of her uncle during the proceedings, the very same Henry, vicar of Swalcliffe, also accused of abduction; permission was granted. The only goods she took with her were her clothes and the ring on her finger-apparently enough to fuel a demand by her husband for compensation of lost goods. ${ }^{71}$ Although this case does not tell us whether an annulment was, in fact, granted, it does make clear why some women may have been hesitant to sue for one. An informal separation, that might easily be explained away as incompatibility, was probably a safer option for most women than a formal and public declaration of male sexual inadequacy.

Many runaway wives were also accused of adultery. Adultery was probably a symptom of a faltering marriage, rather than the cause; however, it is important to note that a woman's adulterous behavior is often what brought her case to the attention of the court in the first place. In his study of the Rochester consistory court, Andrew Finch also noted a possible "bias towards reporting adultery if it involved a married woman" (rather than a single woman having an affair with a married man)..$^{72}$ An inevitable conclusion is that some wives may have been more successful in their desertions if they had managed to stay chaste. Adultery 
may also have made a return to marriage more difficult. Even if she had wanted to, could a woman like Agnes Day have easily returned to her husband after she had borne a child to another man? ${ }^{73}$

\section{The Other Side of the Story}

Husbands offered a much different perspective of why wives left. In some cases, the records explain the wife's departure as having been unreasonable. For example, when Emma wife of Nicholas Swayn left her husband in the year 1360 , she apparently did so "for trivial and fabricated reasons." ${ }^{74}$ Similarly, when Agnes Cossall left her husband, Edward Plompton, the records note that "without cause resonable [she] wilfully departed." wife left "without cause" (sans cause); Leonard Wright of London explained that his wife left "without any licence or cause given by [him]," and he was willing to prove this by "record of his neighbours"; John Tikyll's wife left "without reasonable cause" (sine causa racionabili). ${ }^{76}$ These responses may have been typical defenses of men determined not to be accused of driving their wives away, but in an age where the legacy of Eve loomed large, this may also have been a deliberate attempt to draw on stereotypical images of the "unreasonableness of women." 77 If women lack reason, and are known to act in ways contrary to their best interests, then do we even need to worry about finding a reason why they left their husbands? For a husband who may have provoked his wife's desertion, there could be no better defense.

In other records, the husbands' desire to shift the blame entirely to the wife was more pointed. This could be performed in various ways. Some records offer no explanation for why the wife left, but add tone. For example, a matrimonial suit initiated by Thomas Wycense of Laudwick against his wife Matilda at the court of Canterbury in 1313, argued that his wife "maliciously absents herself" (maliciose se absentante). ${ }^{78} \mathrm{At}$ times, jilted husbands made an ignoble attempt to explain their wives' defection. For example, when Henry Cook of Trottiscliffe and his wife were brought before the court of the bishop of Rochester on Dec. 24 in 1347, the husband claimed "it was not his fault that his wife had left him." Rather, it was apparently his wife's fault for being a scold, even though, admitredly, he had also engaged in adultery and his wife accused him of cruelty ${ }^{79}$ Henry's wife was not the only scold in the lot. Isabella Case, wife of Jankyn Dey of Hereford diocese, was "a common defamer and sustainer of quarrels." 80 Joan Grokles was accused of "customarily leav[ing] her husband for long periods," she was also a scold, "causing quarrels amongst her neighbours," and an adulteress, accused of adultery with one named man and with "strangers." 81 Two wives were accused of being prostitutes. Agnes wife of John Attepole and Katherine wife of John atte Mulle were both described as common prostitutes (communis meretrix/lenocinium fecen't). ${ }^{82}$ Many others were also accused of adultery.

All of these accusations need to be taken with a grain of salt. Cases of desertion appearing in the ecclesiastical courts are examples of marriages in crisis. Just as divorce cases today often break down into expensive bouts of name-calling in the presence of a judge, we see similar accusations flying between estranged husbands and wives in medieval England. Accusations usually divided along gendered lines. Husbands were blamed for cruelty and adultery; wives were im- 
pugned for being scolds and loose women. A shadow of doubt must be cast even on those accusations of prostitution. Meretrix had much the same meaning as the modern term "whore": were these women actually paid prostitutes, or simply women of loose morals ${ }^{83}$ The hostile nature of these disputes prevents us from a clearer understanding of women's motivations for leaving their husbands. At least in cases of judicial separation or annulment, one can be certain that there was substance to the allegations; a court proctor knew better than to take on a case that was unprovable. Otherwise, some caution must be exercised. The records do reveal, however, that wives left marriages for a wide variety of reasons. If cruelty had been the dominant factor, distinguishing these obstinately runaway wives from other cases of marital separation, one might assume that wives only left marriages because their lives were in danger. These runaway wives demonstrate that that was not necessarily the case.

\section{The Logistics of Desertion}

The records also help us answer some of the more fundamental questions about husband desertion. Who were these women? Where did they find help? What happened to them?

Women seem to have deserted their husbands at almost every level of society, the nobility obviously being the one exception to the rule. It is interesting, however, that the gentry, who were often capable of escaping mention in medieval courts of law, were a very noticeable presence in these records. While Lady Margery Longford and Dame Christiana Meynell have already been noted, they were not the only women of substance to have appeared in the legal record, ${ }^{84}$ For example, the records of Archbishop John Le Romeyn from the year 1286 include a mandate to compel Margery wife of Sir German de la Hay, knight, to live with her husband. ${ }^{85} \mathrm{~A}$ record from the bishop of Worcester in 1278 notes the case of Agnes the wife of Sir James de Etyndon, knight, "abducted" by Henry Fown who "publicly detained her in adultery" for five years. ${ }^{86}$ If the allegations of husbands trying to recover their lost goods can be believed, many other runaway wives were fairly well off. Henry Hauke claimed John Bokke made off with his wife and goods worth ten marks; from John Metheu de Tamall, Walter Hankocke and others supposedly ravished his wife and goods worth 20 marks; Agnes wife of Robert Smyth de Kelstern was said to have been abducted along with goods worth 100 shillings. ${ }^{87}$ Some other women clearly were born into money, however the records do not indicate how much. For example, Katherine atte Borwe, cited before the dean of Salisbury for not consorting with her husband Philip, was accused also of refusing to "share any of her goods with him." ${ }^{88}$ Because cases of husband-desertion frequently revolved around money and the division of property, it is not surprising that women from the land-owning class made an appearance in these records. However, a cursory examination of those husbands of runaway wives whose occupations are mentioned in the records supports the hypothesis that women came from a broad spectrum of society. ${ }^{89}$ Runaway wives are reported as being married to farmers, millers, yeomen, merchants, masons, coopers, goldsmiths, and even butchers and cottagers. Indeed, these records reveal that all classes failed to instruct women properly to tolerate unhappy marriages. 
Despite the various threats posed to those who assisted a deserter, as cases mentioned above illustrate, many friends and family members were willing to lend a hand or home to help a runaway wife. What is perhaps most surprising is the repeated appearances of clergymen accused of aiding in husband desertions. Clergymen drawn from a wide variety of positions (from parsons and chaplains, to a vicar, an archdeacon, and even a monk), assisted in fifteen instances of husband desertion. ${ }^{90}$ With the lecherous reputations of clergy in late medieval England, it is hard not to imagine that some, like the chaplain William Fletcher, mentioned above, were also the women's lovers. ${ }^{91}$ Some were reported as family members. ${ }^{92}$ It is also possible, as Sue Sheridan Walker has posited, that clergy. men "may have been acting in their capacity of spiritual advisor." 93 Henry Ansgar Kelly has made a similar point in his analysis of the charges of ravishment leveled against Henry Wakefield, the bishop of Worcester, in 1387. Wakefield was accused of feloniously ravishing the wife and daughter of John Henley, as well as a number of their goods (namely, woolen and linen cloths and other household utensils to the value of 40s.). Although traditionally Wakefield has been viewed as a "rapist," Kelly supposes that this case points instead to "some sort of domestic strife. The bishop or his court may have helped to rescue Joan and Katherine from an abusive household, perhaps effecting a legal separation of Katherine for sevitia [cruelty] ... or an annulment because of an impediment to marriage." 94 Other clergymen may have been carrying out similar curial duties, carrying for the troubled souls of their parishioners.

That many men defied the law and assisted deserters is admirable; however, some assistance was more trouble than it was worth. Such was the case of Joan wife of Hamon Sirich, helped by a man named Stephen de Beck. When Joan and her husband fought over a rumor that Hamon had heard concerning his wife and the very same Stephen, "fearing that her aforesaid husband would have done her evil," Joan left her husband's house and went to stay with another man, whose relationship was not specified, in the same vill. The record does not clarify exactly what the rumor was or whether it was indeed true; it only hints that Stephen, described here as a beneficed clerk, had some sort of prior relationship with Joan. Upon hearing what had happened to Joan, Stephen ordered two of his servants to go and get her, "because she had frequently suffered so many injuries because of [her husband]." She soon came back with Stephen's servants, but not voluntarily. When asked if she went to Stephen's house of her own free will, the jurors replied that she did not, "for they say that she told the aforesaid servants that she would rather return to her husband and take the punishment which he would inflict on her than go with them." Thus, it should come as no surprise that he was accused of ravishment. ${ }^{95}$

Probably the most intriguing question about husband desertion is: what happened to these women? This question is also the most difficult to answer. Unless a wife returned to her husband, her fate is often hidden from the records. Given that fears of economic vulnerability kept many wives in unhappy marriages, a deserter's financial stability must have been a critical concern. The records hint at the dangers single life held for a runaway wife. For example, after leaving her husband, Margery wife of John Roseson of Berkswell, was reported as having feloniously stolen woolen and linen cloth and a copper pan valued at $26 \mathrm{~s} .8 \mathrm{~d}^{96}$ It is not hard to imagine that economic hardship may have driven her to crime. 
Some other women probably lived off the goods that they "stole" from their husbands. Some women lived with their families and friends, and so staved off poverty and vagrancy accordingly. Many women simply went on with their lives and remarried. An ex officio act book from the years 1468-74 notes the case of Agnes Erby of Faversham, summoned before the court of Canterbury for not liv. ing with her husband, and having another husband in Lincoln diocese. ${ }^{97}$ Four of the seventeen other runaway wives from the same act book were similarly accused ${ }^{98}$ Other cases described in the records only as adultery may conceal clandestine marriages, marriages performed in the traditional manner, without the presence of a priest or celebration of the nuptial mass. Clearly, some adulterous relationships were of a long-standing nature. For example, Adam le Coke of Wodicote was accused of "long retaining" Juliana wife of Thomas la Melewarde in adultery. ${ }^{99}$ Out of economic necessity, many women probably had little choice but to rely on a man for assistance.

If we believe the records, some women seem to have passed an inordinate amount of time harassing the very husbands they deserted. For example, a case from Dawlish manor in Devon, 1301, notes that "Agnes Day, the farmer's wife, scorns Nicholas her husband, and he dare not approach her; and this because Matthew, the squire, before he went to Rome, had a child by her, and carried away by this she attacks her husband whenever she sees him, giving him hard words and treating him badly. Should the same Matthew return from Rome, they do not think that he will frequent her." ${ }^{" 100}$ Agnes Day was not the only reportedly abusive wife, although she was one of the few to work alone. Most hostile wives sent their lovers and friends to stalk and abuse their husbands. Stephen Sutor, lover of Agnes wife of John atte Pole, attacked and beat John with Agnes' help, eventually leading to the arrest of both Agnes and Stephen. ${ }^{101}$ Joan Lylle and her "adherents" had her husband "fearing daily to be in jeopardy of his life," and eventually drove him before the chancellor, begging for their arrest. ${ }^{102}$ Other wives purportedly "procured strange persons to lie in wait for the said supplicant to slay him," as John Haket asserted to the chancellor that his wife and her lover had done. ${ }^{103}$ More than one wife showed an adept use of the common law to badger her husband with false suits. ${ }^{104}$ Again, it is simply not possible to accept all of these allegations at face value; they do, however, make it clear to us that flight from marriage did not necessarily entail a wife uprooting herself entirely to start over in another vill.

The broader picture of marital dissolution derived from these case studies is that husband desertion was a more common experience in later medieval England than previously imagined, one in which families and friends were prepared to help out, and may even have believed it was their responsibility to do so. Certainly, the case of Stephen Beck, mentioned above, indicates that some men felt quite strongly about their role in the supervision of marriage and in the need to assist wives wishing to desert their husbands. For many women, life after marriage must have been fraught with fears of economic stability; for many others, life simply went on.

From the early Middle Ages, the Christian church attempted to impose its ideas of marriage as a permanent monogamous institution on a society that, traditionally, had a much more fluid perspective of marriage and the acceptability 
of divorce. ${ }^{105}$ In the early thirteenth century, after declaring that marriage was, in fact, a sacrament, the church redoubled its efforts, and began the move into the bedrooms of medieval Christians, determined to keep marriages together at all costs. Laura Betzig, among others, has recently challenged perceptions that the church was triumphant in imposing permanent monogamous unions on medieval Europeans. Instead, she argues that while the church may have had a taste of success in eliminating polygamy, medieval Christians still mated with a variety of lovers, as evidenced by the numerous clergymen, married to God, who still maintained mistresses and children. ${ }^{106}$ These cases of runaway wives strengthen Betzig's argument, while at the same time, they add a whole new dimension to it. Along with family and friends who chose to abet them, these women risked excommunication, imprisonment, public humiliation, weighty fines, and the threat of death to rebel against the permanence of marriage. The defiance of these women, and the willingness of others to assist, strongly suggests that, although the church regarded marriage as a binding contract between husband and wife, the English people were not as willing to embrace this point of view.

This study of runaway wives helps us to refocus our social lens and achieve a clearer understanding of later medieval wives. While this group of women was a small minority in medieval English society, they do at least suggest that not all wives were desperate housewives.

\section{History Department}

New Orleans, LA 70118

\section{ENDNOTES}

1. Lawrence Stone, The Family, Sex and Marriage 1500-1800 (New York, 1977), p. 117.

2. Judith M. Bennett, Women in the Medieval English Countryside: Gender and Household in Brigstock Before the Plague (Oxford, 1987), p. 103.

3. Ibid.

4. Barbara A. Hanawalt, The Ties that Bound (Oxford, 1986), p. 214; see also her "Violence in the Domestic Milieu of Late Medieval England," in Richard W. Kaeuper, ed., Violence in Medieval Society (Woodbridge, Eng., 2000), pp. 197-214.

5. For a discussion of coverture and a married woman's rights at law, see Janet S. Loengard, "Common Law for Margery: Separate But Not Equal," in Linda E. Mitchell, ed., Women in Medieval Western European Culture (New York, 1999), pp. 117-130.

6. Sara M. Butler, The Language of Abuse: Marital Violence in Later Medieval England. (Brill, forthcoming 2007).

7. Charles Donahue, Jr., "Female Plaintiffs in Marriage Cases in the Court of York in the Later Middle Ages: What Can We Learn from the Numbers?" in Sue Sheridan Walker, ed., Wife and Widow in Medieval England (Ann Arbor, 1993), p. 197.

8. Andrew Finch, "Repulsa uxore sua: Marital Difficulties and Separation in the Later Middle Ages," Continuity and Change 8.1 (1993): 25. 
9. Donahue, "Female Plaintiffs," p. 205.

10. R.H. Helmhol2, Marriage Litigation in Medieval England (Cambridge, Mass., 1974), p. 62 .

11. Sue Sheridan Walker, "Common Law Juries and Feudal Marriage Customs in Medieval England: The Pleas of Ravishment," University of Illinois Law Review (1984): 70518; Sue Sheridan Walker, "Punishing Convicted Ravishers: Statutory Strictures and Actual Practice in Thirteenth and Fourteenth-Century England," Joumal of Medieval History 13 (1987): 237-50; Henry Ansgar Kelly, "Statutes of Rapes and Alleged Ravishers of Wives: a Context for the Charges against Thomas Malory, Knight," Viator 28 (1997): 361-419.

12. Daniel Klerman, "Jurisdictional Competition and the Evolution of the Common Law: An Hypothesis," in Anthony Musson, ed., Boundaries of the Law: Geography, Gender and Jurisdiction in Medieval and Early Modern Europe (Aldershot, Eng, 2005), pp. 149-68.

13. For example, a Canterbury ex officio act book for the years 1468-74 records 42 cases of reprimands for spousal non-cohabitation. See Canterbury Cathedral Archives (hereafter abbreviated as 'Canterbury') Y.1.11.

14. See Sara M. Butler, "Maintenance Agreements and Male Responsibility in Later Medieval England," in A.J. Musson, ed., Boundaries of the Law, pp. 68-83.

15. Westminster II, c. 34, The Statutes of the Realm, 12 vols. (London 1810-1828; repr. 1963), 1.87.

16. Ruth Mazo Karras, "Sex and the Singlewoman," in Judith M. Bennett and Amy M. Froide, eds, Singlewomen in the European Past, 1250-1800 (Philadelphia, 1999), p. 34

17. Judith M. Bennett and Amy M. Froide, "A Singular Past," in their Singlewomen in the European Past, p. 13.

18. See James A. Brundage, "Domestic Violence in Classical Canon Law," in Richard W. Kaeuper, ed., Violence in Medieval Society (Boydell, 2000), pp. 183-95.

19. For example, see Agnes Curtyes de Est Deping, in Margaret Bowker, ed., An Episcopal Court Book for the Diocese of Lincoln 1514-1520 (The Lincoln Record Society, v. 61, 1967), p. 88; Pleasaunce Ovenhille, the wife of John de Davy of Aylesford, in Charles Johnson, ed., Registrum Hamonis Hethe, Diocesis Roffensis, A.D. 1319-1352, v. 1 (Canterbury and York Society, v. 48, 1948), pp. 197 and 227-8; Juliana wife of Thomas la Melwarde, in Earnest Harold Pearce, ed., The Register of Thomas de Cobham Bishop of Worcester 1317-1327 (Worcestershire Historical Society, 1930), p. 192. For an excellent discussion of excommunication, see Elisabeth Vodola, Excommunication in the Middle Ages (Berkeley, 1986).

20. L.R. Poos, ed., Lower Ecclesiastical Jurisdiction in Late-Medieval England: the Courts of the Dean and Chapter of Lincoln, 1336-1349, and the Deanery of Wisbech, 1458-1484 (Records of Social and Economic History, New Series 32, 2001), p: 6.

21. Ibid., p. 368.

22. T.C.B. Timmins, ed., The Register of John Waltham, Bishop of Salisbury, 1388-1395

(Canterbury and York Society, v.80, 1994), p. 150, no. 1095; p. 151, no. 1096. 
23. E.F. Jacob, ed., The Register of Henry Chichele, Archbishop of Canterbury, 1414-1443 (Canterbury and York Society, v. 47), pp. 185-6.

24. R.L. Storey, ed., The Register of Thomas Langley, Bishop of Durham, 1406-1437 (Surtees Society, v. 166, 1951), p. 134.

25. The Wakefield rolls, for example, address a marriage-related case roughly every three years.

26. J.W. Walker, ed., Court Rolls of the Manor of Wakefield, v. 5: 1322-1331 (Yorkshire Archaeological Society, v. 109, 1944), p. 189.

27. The abduction of goods and chattels, in addition to the wife, seems to have been an addition of the statute of Westminster II (1285). However, this language was incorporated into the writ De uxore rapta (seizure of a wife), and thus it can be assumed was an integral part of the suit. See Elsa de Haas and G.D.G. Hall, eds, Early Register of Writs (London, 1970), p. 181.

28. J.B. Post, "Ravishment of Women and the Statutes of Westminster," in J.H. Baker, ed., Legal Records and the Historian (London, 1978), p. 158.

29. Morris S. Arnold, ed. and trans., Select Cases of Trespass from the King's Courts 13071399 , v. 1 (Selden Society, v. 100, 1985), p. 80, no. 8.6 (The National Archives, Kew, Surrey [hereafter abbreviated as TNA] KB 27/225, m. 1).

30. Select Cases of Trespass, pp. 80-1, no. 8.7 (TNA KB 27/232, m. 64d).

31. Select Cases of Trespass, pp. 89-90, no. 817 (TNA KB 27/514, m. 19).

32. Maureen Mulholland, "Trial in manorial courts in late medieval England," in Maureen Mulholland and Brian Pullan, eds, Judicial tribunals in England and Europe, 12001700: The Trial in history, volume I (Manchester, 2003), p. 88.

33. The necessity that the case involves substantial goods was not spelled out in statute law until 1487, 3 Henry VII, c. 2, The Statutes of the Realm, 2.512. For a discussion of the 1487 act, see E.W. Ives, "'Agaynst taking awaye of Women': the Inception and Operation of the Abduction Act of 1487," in E.W. Ives, R.J. Knecht and J.J. Scarisbrick, eds, Wealth and Power in Tudor England: Essays Presented to S.T. Bindoff (London, 1978).

34. Alan Macfarlane, ed., Earls Colne, Essex: Records of an English Village, 1375-1854 (University of Cambridge), http://linux02.lib.cam.ac.uk/earlscolne/ecrolls2/ 54201104.htm, no. 16.5.1402 (Essex Record Office D/DPr66).

35. Select Cases of Trespass, pp. 73-4, no. 8.1 (TNA KB 27/191, m. 7). Walker does note it was possible to be pardoned for ravishment; however, a pardon only forgave what was due to the crown, not to the plaintiff. See Walker, "Punishing Convicted Ravishers," 245.

36. Emma Hawkes, "'She was ravished against her will, what so ever she say': Female Consent in Rape and Ravishment in late-medieval England," Limina 1 (1995): 47.

37. For a discussion of the dangers of such confusing terminology, see Christopher Cannon, "Raptus in the Chaumpaigne Release and a Newly Discovered Document Concerning the Life of Geoffrey Chaucer," Speculum 68 (1993): 74-94. 
38. Hawkes, 48.

39. Elizabeth Chapin Furber, ed., Essex Sessions of the Peace 1351, 1377-79 (Essex Archaeological Society, 1953), p. 98, no. A42.

40. Elisabeth Guernsey Kimball, ed., Rolls of the Warwickshire and Coventry Sessions of the Peace 1377-1397 (Dugdale Society, v. 16, 1939), p. 151, no. 133.

41. Essex Sessions of the Peace, p. 169, no. B192.

42. Bertha Haven Putnam, Yorkshire Sessions of the Peace, 1361-64 (Yorkshire Archaeological Society, v. 100, 1939), p. 34, no. 8.

43. T.D. Hardy, ed., Registrum Palatinum Dunelmense (Rolls Series, v. 62, 1873-8), pt. 3, p. 281.

44. See also the records of the Deanery of Wisbech from the year 1464 which note the case of Roger Palfrayman who detains the wife of John Botery. He is warned to remove her and return her to her husband, under pain of judgment. He is not described as her lover, as the church was usually very careful to do. Was he another well-meaning neighbor or brother trying to help a runaway wife? Lower Ecclesiastical Jurisdiction, p. 479. See also R.L. Storey, ed., The Register of Thomas Langley, Bishop of Durham, 1406-1437, v. 3 (Surtees Society, v. 169,1954$)$, p. 65 , no. 695 .

45. William Paley Baildon, ed., Court Rolls of the Manor of Wakefield, v. 1: 1274-1297 (Yorkshire Archaeological Society, v. 29, 1900), p. 234. The resolution to this case does not seem to have survived, although both John and Cicely turn up in later records. Cicely appears at another tourn in November of 1296 for brewing weak ale (p. 244), and John of Sibbe appears as a pledge in a brush-wood case in 1297 (p. 271).

46. At least one wife in this sampling returned of her own initiative. A tourn from the year 1307 at Wakefield describes the case of Alice wife of John Kyde of Wakefield who participated in a consensual abduction by Nicholas, the parish chaplain of Wakefield. Although the record notes that "afterwards Alice returned to her husband," the very long list of items taken with her and their value would suggest that John Kyde was hoping to receive compensation for the items she did not bring home. William Paley Baildon, ed., Court Rolls of the Manor of Wakefield, v. 2 (1297 to 1309) (Yorkshire Archaeological Society, v. 36, 1906), p. 93.

47. T.C.B. Timmins, ed., The Register of John Chandler Dean of Salisbury 1404-17 (Wiltshire Record Society, v. 39, 1984), pp. 112-3, no. 315.

48. "pertractandum ipsum pacifice et quiete et eidem humiliter obediat et ad iram non provocet." Lower Ecclesiastical Jurisdiction, p. 219.

49. Two examples: Emma wife of Nicholas Swayn was told to obey her husband in conjugal duties (R.L. Storey, ed., The Register of Gilbert Welton, Bishop of Carlisle, 1353-1362 [Canterbury and York Society, v. 88, 1999], p. 63, no. 349); Agnes Curteys of Est Deping was also required to promise to obey her husband (An Episcopal Court Book for the Diocese of Lincoln, p. 88). This issue is discussed at greater length in Butler, The Language of Abuse. 
50. J.W. Willis Bund, ed., Episcopal Registers, Diocese of Worcester. Register of Bishop Godfrey Giffard, September 23rd, 1268 to August 15th, 1301 (Worcestershire Historical Society, 1902), p. 76.

51. A.T. Bannister, ed., "Visitation returns of the diocese of Hereford in 1397," English Historical Review 45 (1930), 92.

52. A. Hamilton Thompson, ed., Visitations in the Diocese of Lincoln 1517-1531: Volume 1: Visitations of Rural Deaneries by William Atwater, Bishop of Lincoln, and his Commissaries, 1517-20 (The Lincoln Record Society, v33., 1940), p. 139.

53. Register of Gilbert Welton, p. 63, no. 349; Register of John Chandler, p. 116, no. 331.

54. E.M. Elvey, ed., The Courts of the Archdeaconry of Buckingham 1483-1523 (Buckinghamshire Record Sociery, no. 19, 1975), p. 250.

55. See Helmholz, Marriage Litigation, chapter three.

56. Register of John Waltham, p. 146, no. 1016.

57. Register of John Chandler, pp. 96-7, no. 262.

58. Visitations in the Diocese of Lincoln 1517-1531, p. 47.

59. Register of John Waltham, p. 117, no. 929.

60. See above, note 23 .

61. A.H. Thomas, ed., Calendar of Early Mayor's Court Rolls of the City of London, a.d. 1298-1307 (Cambridge, Eng., 1924), pp. 236-7. These are not the only cases where the wives were in the process of formalizing their separations.

62. For example, see Select Cases of Trespass, pp. 86-7, no. 8.14 (TNA KB 27/50, m. 36), or pp. 92-3, no. 8.19 (TNA KB 27/518, m. 32d); TNA C 1/343/63, John Obyn, of London, mason. v. The sheriffs of London (1500-1515), in which John Obyn of London argues that his wife's assertion of precontract with William Sharpe is merely "pretended."

63. Select Cases of Trespass, pp. 82-3, no. 8.10 (TNA KB 27/434, m. 26d).

64. Theoretically, a wife could also obtain a separation for heresy or adultery (both on her husband's part), however English women do not seem to have resorted to appeals of this nature. See my forthcoming book, The Language of Abuse.

65. Courts of the Archdeaconry of Buckingham, p. 250.

66. Charles Johnson, ed., Registrum Hamonis Hethe, Diocesis Roffensis, A.D. 1319-1352, v. 2 (Canterbury and York Society, vol. 48, 1948).

67. W. Brown, ed., The Register of John Le Romeyn, Lord Archbishop of York 1286-1296, part 1 (Surtees Society, v. 123), pp. 170 and 176-7.

68. Select Cases of Trespass, p. 92, no. 8.9 (TNA KB 27/422, m. 42).

69. Helmholz, Marriage Litigation, pp. 88-9. 
70. Canterbury X.8.1 Ex officio Act Book (1395-1410), fol. 44d.

71. Select Cases of Trespass, p. 87, no. 8.15 (TNA KB 27/509, m. 26).

72. Andrew John Finch, "Sexual morality and canon law: The evidence of the Rochester consistory court," Journal of Medieval History 20 (1994): 270.

73. P.E. Hair, ed., Before the Bawdy Court: Selections from Church Court and Other Records relating to the Correction of Moral Offences in England, Scotland, and New England, 13001800 (New York, 1972), p. 118, no. 274.

74. R.L. Storey, ed., The Register of Gilbert Welton, Bishop of Carlisle, 1353-1362 (Canterbury and York Society, v. 88, 1999), p. 63, no. 349. This description was not femalespecific. For example, when Christopher of Lancaster left his wife Joan, he was said to have done so "for frivolous and fictitious reasons." (p. 104, no. 55).

75. TNA C 1/239/56, Piers Forster, tailor, of London. v. Edward Cheseman and William Curtas (1500-1515).

76. TNA C 1/68/106, Robert Barbour v. Walter Herford, monk of St. Peter's, Gloucester (1386-1486); TNA C 1/693/8, Leonard Wryght of London, cooper. v. Joan, wife of the said Leonard, formerly Lylle (1529-32); Register of Thomas Langley, v. 177 (1962), pp. 110-111, no. 1404 .

77. Shawn Madison Krahmer, "Adam, Eve, and Original Sin in the Works of Bernard of Clairvaux," Cistercian Studies Quarterly 37.1 (2002): 5, 9-10.

78. Canterbury, SVSB I 113.

79. See note 66 .

80. "Visitation returns of the diocese of Hereford in 1397," 100.

81. Register of John Chandler, p. 4, no. 4 .

82. Warren Ortman, ed., Court Rolls of the Abbey of Ramsey and of the Honor of Clare (Yale Historical Publications, v. 9, 1928), p. 252; Register of John Chandler, pp. 112-13, no. 315 .

83. Karras,"Sex and the Singlewomen," pp. 130-131.

84. See above, note 23 .

85. John Le Romeyn, p. 191

86. Despite manifold warnings, the couple persisted in their adultery, until Agnes died in Henry's "unlawful embraces." Register of Bishop Godfrey Giffard, pp. 95 and 98.

87. T. Walter Hall, ed., A Descriptive Catalogue of Sheffield Manorial Records from the 8th Year of Richard II to the Restoration (Sheffield, Eng., 1920), v. 1, p. 34; TNA C 1/45/46, John Maetheu de Tamall, yeoman, vs. Walter Hankocke and others, of St. Cue (146770); Rosamond Sillem, ed., Records of Some Sessions of the Peace in Lincolnshire 1360-1375 (Lincoln Record Society, v. 30, 1936), pp. 20-21.

88. Register of John Walcham, p. 146, no. 1016. 
89. Unfortunately, most ecclesiastical records do not mention the occupation of the husband.

90. "Visitation returns of the diocese of Hereford in 1397," p. 92, John Comyn, chaplain of Collewalle; Putnam, Yorkshire Sessions of the Peace, p. 26, no. 100, Thomas de Wartre, chaplain; Baildon, Court Rolls of the Manor of Wakefield, v. 2, p. 93, Alice wife of John Hyde of Wakefield abducted at the parish chaplain's command; William Hudson, ed., Leet Jurisdiction in the City of Norwich: during the XIIIth and XIVth Centuries (Selden Society, v. 5, 1891), p. 67, Walter Quell, chaplain; TNA C 1/75/39, Thomas Gwyn v. Thomas Colle, parson of Combe Merton (1386-1486); TNA C 1/68/106, Robert Barbour v. Walter Herford, monk of St. Peter's, Gloucester (1386-1486); Rolls of the Warwickshire and Coventry Sessions of the Peace, p. 160, no. 18, William Flecther, chaplain; Essex Sessions of the Peace, p. 98, no. A42, Roger de Harleston, archdeacon of Cambridge; ibid, p. 169, no. B192, William Beverel, chaplain; ibid, p. 171, no. B207, William rector of the church of Chignall St. James; ibid, p. 203, no. B279, Thomas Isbroud, chaplain; Records of Some Sessions of the Peace in Lincolnshire, p. 208, Robert son of John Haliday of Morton, chaplain; Select Cases of Trespass, pp. 78-9, no. 8.5 (TNA KB 27/225, m. 87d), Stephen de Beck, a beneficed clerk; ibid, p. 81, no. 8.8 (TNA KB 27/295, m. 2d), John, Parson of Newbold Pacey; ibid, pp. 87-8, no. 8.15 (TNA KB 27/509, m. 26), Henry, Vicar of Swalcliffe.

91. For a discussion of the continuing problem of sexually active clergy see Bernhard Schimmelpfennig, "Ex fornicatione nati: Studies on the position of priests' sons from the twelfth to the fourteenth century," Studies in Medieval and Renaissance History, n.s. 2, o.s. 12 (1979): 3-50.

92. Such was the case with Henry, vicar of Swalcliffe.

93. Walker, "Punishing Convicted Ravishers," 245-6.

94. Kelly, "Statutes of Rape," 408.

95. Select Cases of Trespass, pp. 78-9, no. 8.5 (TNA KB 27/225, m. 87d).

96. Rolls of the Warwickshire and Coventry Sessions of the Peace, p. 123, no. 20.

97. Canterbury Y.1.11, fol. 120.

98. Agnes Edward of St Mary's parish in Northgate, Canterbury Y.1.11, fol;. 55; Mariora Pokelyn, Canterbury Y.1.11, fol;. 156d; Elena Dryykdestor of St Agatha, Canterbury Y.1.11, fol. 183d; Joanna Boyce de Thornton, Canterbury Y.1.11, fol. 337.

99. Register of Thomas de Cobham, p. 192.

100. Before the Bawdy Court, p. 118 , no. 274.

101. Court Rolls of the Abbey of Ramsey, p. 246.

102. TNA C $1 / 693 / 8$, Leonard Wryght of London, cooper. v. Jone, wife of the said Leonard, formerly Lylle (1529-32).

103. TNA C 1/71/139, John Haket v. Nicholas Moungumrey alias Shyrley, of Salisbury (1386-1486). 
104. See Sara M. Butler, "The Law as a Weapon in Marital Disputes: Evidence from the Late Medieval Court of Chancery, 1424-1529," Joumal of British Studies 43.3 (2004): 291-316.

105. Jo-Ann McNamara and Suzanne F. Wemple, "Marriage and Divorce in the Frankish Kingdom," in Susan Mosher Stuard, ed., Women in Medieval Society (Philadelphia, 1976), pp. 95-124.

106. Laura Betzig, "Medieval Monogamy," Journal of Family History 20.2 (1995): 181216. See also Art Cosgrove, "Consent, consummation and indissolubility: some evidence from medieval ecclesiastical courts," Dounside Review 109 (1991): 94-104; Frederik Pedersen, Marriage Disputes in Medieval England (Hambledon, 2000); L.R. Poos, "The HeavyHanded Marriage Counselor: Regulating Marriage in Some Later-Medieval English Local Ecclesiastical Court Jurisdictions," American Journal of Legal History 29 (1995): 291-309. 
Copyright of Journal of Social History is the property of George Mason University and its content may not be copied or emailed to multiple sites or posted to a listserv without the copyright holder's express written permission. However, users may print, download, or email articles for individual use. 